\title{
Penggunaan Komik Dalam Media Pembelajaran Fisika Menggunakan Model POE2WE
}

\author{
Suci Khoirun Nisa ${ }^{1}$, Nana ${ }^{2}$ \\ Program Studi Pendidikan Fisika, Fakultas Keguruan dan Ilmu Pendidikan Universitas Siliwangi \\ Jl. Siliwangi No.24, kahuripan,kec. Tawang, Tasikmalaya, 46114, Indonesia.

\section{E-mail: sucikhoirunnisa7@ gmail.com}

\begin{abstract}
Abstrak
Penelitian ini bertujuan untuk : (1) Mendeskripsikan langkah-langkah penerapan pelajaran Fisika SMA dengan model POE2WE ,(2) Menjelaskan penggunaan komik dalam media pembelajaran fisika , (3) Menjelaskan manfaat komik dalam meningkatkan daya baca siswa ke dalam buku pelajaran. Penelitian ini menggunakan metode studi pustaka. Penggunaan komik dalam media pembelajaran fisika untuk menarik minat baca siswa.

Kata kunci: komik, POE2WE,media pembelajaran

Abstract

This study aims to: (1) Describe the steps of applying high school physics lessons with the POE2WE model, (2) Explain the use of comics in physics learning media, (3) Explain the benefits of comics in increasing students' reading power into textbooks. This research uses literature study method. The use of comics in physics learning media to attract students' reading interest.
\end{abstract}

Keywords: comics, POE2WE, learning media

\begin{abstract}
Pendahuluan
Pembelajaran kurikulum 2013 adalah pembelajaran kompetensi dengan memperkuat proses pembelajaran dan penelitian autentik untuk mencapai kompetensi sikap, pengetahuan dan ketrampilan. Penguatan proses pembelajaran dilakukan melalui pendekatan saintifik, yaitu pembelajaran yang mendorong siswa lebih mampu dalam mengamati, menanya, megumpulkan data, mengasosiasi/menalar, dan mengkomunikasikan.

Sejalan dengan pembelajaran kurikulum 2013, dalam upaya meningkatkan pemahaman peserta didik mengenai konsep dan materi pembelajaran fisika maka diperlukan sebuah model pembelajaran yang dapat memfasilitasi peserta didik untuk lebih kritis dan terlibat aktif dalam proses pembelajaran. Pada peggunaan model POE2WE peserta didik diajak untuk berinteraksi dan berdiskusi melalui serangkaian kegiatan seperti membuat prediksi, merancang percobaan, melakukan percobaan, berdiskusi dalam menjawab pertanyaan LKS dan berinteraksi dalam tanya jawab pada saat presentasi kelompok. Pada pelaksanaan pembelajaran dengan model POE2WE siswa dibeikan tugas untuk membuat laporan praktikum berdasarkan hasil model yang telah
\end{abstract}


dilakukan. Selain dedan model POE2WE peserta didik juga dibantu dengan menggunakan komik sebagai media pembelajaran karena komik dinilai lebih mudah diingat oleh siswa karena menggunakan gambar sebagi penyampaian materi fisika.

Menurut Gene Yang (dalam Herliani,dkk,2013), "Komik memiliki lima kelebihan jika dipakai dalam pembelajaran: 1), yaitu: (1) Memotivasi; (2) Visual; (3) Permanen; (4) Perantara; (5) Populer".Untuk lebih rinci dapat dijelaskan sebagai berikut:

1. Memotivasi

Komik dengan gambar yang menarik dapat meningkatkan partisipasi individu sehingga dapat memotivasi belajar siswa. Meningkatnya motivasi belajar siswa dapat mempermudah pembelajaran siswa. sehingga pembelajaran menjadi mudah.

2. Visual

Komik terdiri dari gambar-gambar yang merupakan media visual. Media visual dapat memperlancar pemahaman dan memperkuat ingatan. Visual dapat pula menumbuhkan minat siswa dan dapat memberikan hubungan antara isi materi pelajaran dengan dunia nyata. Kualitas gambar komik dapat meningkatkan kualitas pembelajaran.

3. Permanen

Menggunakan komik sebagai media pembelajaran berbeda dengan menggunakan film atau animasi. Meskipun film dan animasi juga merupakan media visual, mereka hanya dapat dilihat tanpa bisa mengulanginya sekehendak kita. Komik berbeda dengan film atau animasi, merupakan media yang permanen. Jika siswa tidak memahami suatu adegan film atau animasi, mereka tidak bisa mengulanginya. Tapi dengan komik, mereka bisa mengulangi sesuka hati mereka.

4. Perantara

Komik dapat mengarahkan siswa untuk disiplin membaca khususnya bagi yang tidak suka membaca. Komik dapat berfungsi sebagai perantara dalam penyampaian materi pembelajaran kepada siswa sehingga siswa dapat lebih mudah memahami materi pembelajaran..

\section{Populer}

Timothy Morrison, Gregory Bryan, and George Chilcoat (dalam Herliani,dkk,2013) mengatakan bahwa "Dengan memasukkan budaya populer dalam kurikulum bisa menjembatani kesenjangan perasaan siswa ketika di dalam dan luar sekolah" .Derry Mayendra, (dalam Herliani,dkk,2013) Komik adalah bagian dari budaya populer karena sebelumnya proses pembelajaran hanya menggunakan buku teks biasa. Spiderman and Batman adalah film yang diambil dari komik yang dapat berpengaruh terhadap keberhasilan siswa dalam proses belajar.

Dorrell, Curtis, \& Rampal, (dalam Herliani,dkk,2013) mengatakan bahwa "komik dituduh sebagai musuh membaca serius". Tetapi asumsi-asumsi negatif tentang komik tidak lagi ditemukan di ruang pembelajaran hingga berlanjut sampai 1970an. Robert Schoof menganggap bahwa "Komik berguna untuk pembelajaran bahasa, khususnya dalam mengajarkan dialek dankarakterisasi" 
Menurut Sones (dalam Herliani,dkk,2013), "Many of these experiments have been in the field of language, and on the level of the middle grades and junior high school. Harold Downes, instructor in English in Lynn, with assistance of the publishers of Superman-D.C comic magazine, prepared a workbook in language" (Banyak percobaan dalam bidang bahasa, dan pada tingkat tengah dan sekolah menengah pertama. Harols Downes, pengajar di Inggris di Lynn, dengan asisten penerbit komik Superman, menyiapkan buku kerja dalam bahasa).

Model pembelajaran Prediction, Observation, Explanation, Elaboration, Write dan Evaluation $\left(\mathrm{POE}_{2} \mathrm{WE}\right)$ dikembangkan dari model pembelajaran POEW dan model pembelajaran Fisika dengan Pendekatan Konstruktivistik. Pengembangan ini dilakukan untuk sebagai penyempurnaan kedua model sebelumnya. Model $\mathrm{POE}_{2} \mathrm{WE}$ merupakan model pembelajaran yang dikembangkan untuk mengetahui pemahaman peserta didik mengenai suatu konsep dengan pendekatan konstruktivistik. Model ini membangun pengetahuan dengan urutan proses yaitu meramalkan atau memprediksi solusi dari permasalahan, melakukan eksperimen untuk membuktikan prediksi, kemudian menjelaskan hasil eksperimen yang diperoleh secara lisan maupun tertulis, membuat contoh penerapan dalam kehidupan sehari- hari, menuliskan hasil diskusi dan memuat evaluasi tentang pemahaman peserta didik baik secara lisan maupun tertulis (Nana et al., 2014).

\section{Metode penelitian}

Penelitian ini menggunakan metode literasi (studi pustaka) dengan cara mengkaji berbagai literatul yang berkaitan dengan penerapan model POE2WE,media pembelajaran serta komik.

\section{Hasil penelitian dan pembahasan}

Model pembelajaran Prediction, Observation, Explanation, Elaboration, Write dan Evaluation $\left(\mathrm{POE}_{2} \mathrm{WE}\right.$ ) dikembangkan dari model pembelajaran POEW dan model pembelajaran Fisika dengan Pendekatan Konstruktivistik. Pengembangan ini dilakukan untuk sebagai penyempurnaan kedua model sebelumnya. Model $\mathrm{POE}_{2} \mathrm{WE}$ merupakan model pembelajaran yang dikembangkan untuk mengetahui pemahaman peserta didik mengenai suatu konsep dengan pendekatan konstruktivistik. Model ini membangun pengetahuan dengan urutan proses yaitu meramalkan atau memprediksi solusi dari permasalahan, melakukan eksperimen untuk membuktikan prediksi, kemudian menjelaskan hasil eksperimen yang diperoleh secara lisan maupun tertulis, membuat contoh penerapan dalam kehidupan sehari- hari, menuliskan hasil diskusi dan memuat evaluasi tentang pemahaman peserta didik baik secara lisan maupun tertulis (Nana et al., dalam Nana,dkk , 2019).

Model pembelajaran $\mathrm{POE}_{2} \mathrm{WE}$ dapat menjadikan peserta didik sebagai subjek di dalam pembelajaran. peserta didik secara aktif menemukan suatu konsep melalui pengamatan atau eksperimen secara langsung, bukan dari menghafal buku materi maupun penjelasan dari guru. Model ini memungkinkan peserta didik aktif dalam proses pembelajaran, memberikan kesempatan kepada peserta didik untuk mengkonstrukssi pengetahuannya, mengkomunikasikan pemikirannya dan menuliskan hasil diskusinya sehingga peserta didik lebih menguasai dan memahami konsep yang akan berdampak pada peningkatan prestasi belajar peserta didik Model ini memberikan kesempatan kepada peserta didik untuk melakukan konstruksi pengetahuan yang dimilikinya, melakukan pengamatan terhadap fenomena serta mengkomunikasikan gagasan yang dia perolah dari proses diskusi sehingga peserta didik akan lebih mudah menguasai konsep yang 
diajarkan (Nana, 2014, 2016; Nana et al., 2014; Permatasari, 2011; Rahayu et al., 2013; Samosir, 2010. Dalam Nana,dkk ,2019).

Penggabungan tahapan-tahapan pembelajaran model POEW dan model pembelajaran Fisika dengan Pendekatan Konstruktivistik maka dapat di susun langkah-langkah pembelajaran model $\mathrm{POE}_{2} \mathrm{WE}$ secara terinci sebagai berikut:

a) Prediction

Tahap prediction yaitu peserta didik membuat prediksi atau dugaan awal terhadap suatu permasalahan. Permasalahan yang ditemukan berasal dari pertanyaan dan gambar tentang materi yang disampaikan oleh guru yang ada di Lembar Kerja peserta didik (LKS)/buku peserta didik sebelum peserta didik membuat prediksi. Pembuatan prediksi jawaban tahap Prediction pada model POEW identik dengan fase Engagenent pada pendekatan konstruktivistik. Guru mengajukan pertanyaan yang dapat mendorong peserta didik untuk dapat membuat prediksi atau jawaban sementara dari suatu permasalahan.

b) Observation

Tahap Observation yaitu untuk membuktikan prediksi yang telah di buat oleh pesera didik. Peserta didik diajak melakukan eksperimen berkaitan dengan masalah atau persoalan yang di temukan. Selanjutnya peserta didik mengamati apa yang terjadi, kemudian peserta didik menguji kebenaran dari dugaan sementara yang telah dibuat. Tahap Observation pada model POEW identik dengan fase Exploration pada pendekatan konstruktivistik.

c) Explanation

Tahap Explanation atau menjelaskan yaitu peserta didik memberikan penjelasan terhadap hasil eksperimen yang telah dilakukan. Penjelasan dari peserta didik dilakukan melalui diskusi dengan anggota kelompok kemudian tiap kelompok mempresentasikan hasil diskusinya di depan kelas. Jika prediksi yang di buat peserta didik ternyata terjadi di dalam eksperimen, maka guru membimbing peserta didik merangkum dan memberi penjelasan untuk menguatkan hasil eksperimen yang dilakukan. Namun jika prediksi peserta didik tidak terjadi dalam eksperimen, maka guru membantu peserta didik mencari penjelasan mengapa prediksi atau dugaannya tidak benar. Tahap explanation identik dengan fase explanation pada pendekatan konstuktivistik.

d) Elaboration

Tahap elaboration yaitu peserta didik membuat contoh atau menerapkan konsep dalam kehidupan sehari-hari. Tahap elaboration di ambil dari pendekatan konstruktivistik. Tahap ini guru medorong peserta didik untuk menerapkan konsep baru dalam situasi baru sehingga peserta didik lebih memahami konsep yang di ajarkan guru. Tahap ini pengembangan dari pendekatan konstruktivistik.

e) Write

Tahap write atau menulis yaitu melakukan komunikasi secara tertulis,merefleksikan pengetahuan dan gagasan yang dimiliki peserta didik Menurut Masingilia dan Wisniowska (1996) dalam (Yamin \& Ansari, 2012) menulis dapat membantu peserta didik untuk mengekspresikan pengetahuan dan gagasan mereka. peserta didik menuliskan hasil diskusi dan menjawab pertanyaan yang ada pada LKS. Selain itu pada tahap write ini, peserta didik membuat kesimpulan dan laporan dari hasil eksperimen. Tahap ini merupakan pengembangan dari model TTW.

f) Evaluation

Tahap Evaluation yaitu evaluasi terhadap pengetahuan, keterampilan dan perubahan proses berfikir peserta didik. Pada tahap ini peserta didik di evaluasi tentang materi gerak lurus 
berupa lisan maupun tulisan. Tahap ini merupakan pengembangan dari pendekatan konstruktivistik.

Menurut Scout McCloud (dalam Fikroturrofiah, 2015) memberikan pendapat bahwa komik dapat memiliki arti gambar-gambar serta lambang lain yang terjukstaposisi (berdekatan, bersebelahan) dalam urutan tertentu, untuk menyampaikan informasi dan mencapai tanggapan estetis dari pembacanya. Komik sesungguhnya lebih dari sekedar cerita bergambar yang ringan dan menghibur. Komik adalah suatu bentuk media komunikasi visual yang mempunyai kekuatan untuk menyampaikan informasi secara popular dan mudah dimengerti. Hal ini dimungkinkan karena komik memadukan kekuatan gambar dan tulisan, yang dirangkai dalam suatu alur cerita gambar membuat informasi lebih mudah diserap. Teks membuatnya lebih dimengerti, dan alur membuatnya lebih mudah untuk diikuti dan diingat.

Rohani (dalam Fikroturrofiah, 2015) media komik merupakan media yang mempunyai sifat sederhana, jelas, mudah dipahami dan lebih bersifat personal sehingga bersifat informatif dan edukatif. Menurut Waluyanto (dalam Fikroturrofiah, 2015) komik sebagai media pembelajaran merupakan alat yang berfungsi untuk menyampaikan pesan pembelajaran. Dalam konteks ini pembelajaran menunjuk pada sebuah proses komunikasi antara pelajar (siswa) dan sumber belajar (dalam hal ini komik pembelajaran). Komunikasi belajar akan berjalan dengan maksimal jika pesan pembelajaran disampaikan secara jelas, runtut, dan menarik.

\section{Kesimpulan}

Penggunaan komik sebagai media pembelajaran dengan model POE2WE dirasa cukup baik untuk materi fisika karena mampu membantu peserta didik dalam memahami materi pembelajaran yang dirasa sulit dimengerti, juga penggunaan gambar mampu merangsang daya baca siswa.

\section{Ucapan Terima Kasih}

Segala puji dan syukur kami panjatkan kehadirat Allah SWT yang telah melimpahkan rahmat dan hidayah-Nya kepada kita semua. Shalawat serta salam semoga tercurah kepada Rasulullah SAW beserta keluarganya. Adapun dalam kesempatan ini peneliti ingin mengucapan terimakasih kepada :

1. Dr. Nana M.Pd. selaku dosen pengampu mata kuliah fisika sekolah II.

2. Semua pihak yang tidak bisa disebutkan satu persatu. 


\section{Daftar Pustaka}

Avrilliyanti H,dkk.2013. Penerapan Media Komik Untuk Pembelajaran Fisika Model Kooperatif Dengan Metode Diskusi Pada Siswa Smp Negeri 5 Surakarta Kelas Vii Tahun Ajaran 2011/2012 Materi Gerak. Jurnal Pendidikan Fisika (2013) Vol.1 No.1 halaman 157-158

Fikroturrofiah.2015. Komik Sebagai Media Pembelajaran. https://www.eurekapendidikan.com/2015/02/komik-sebagai-media-pembelajaran.html

Nana,dkk. 2019. Pengembangan Inovasi Pembelajaran Digital Menggunakan Model Blended $\mathrm{POE}_{2} W E$ di Era Revolusi Industri 4.0. Prosiding SNFA (Seminar Nasional Fisika dan Aplikasinya) 2019. 